\title{
EDITORIAL
}

\section{CARDIOPATIA \\ E PARASITISMO NO CHAGÁSICO CRÔNICO}

Enquanto a miocardite aguda chagásica se acompanha de rico parasitismo ${ }^{18}$, de modo a deixar pouca dúvida quanto à participação do Trypanosoma cruzi no aparecimento da reação inflamatória, esta relação deixa de existir na fase crônica, notandose nos chagásicos falecidos em insuficiència cardiaca uma desproporção entre grau de lesão e parasitismo miocárdico. Pode-se mesmo dizer que, a maioria das descriçôes microscópicas, seja do coração, seja do tubo digestivo, não relatam parasitismo tissular na fase crônica da doença. Estes fatos, por si suficientes para levantar dúvidas sobre a necessidade da persistência da infecção tripanossomótica na evolução da cardiopatia, forarm reforçados pela aceitação da teoria neurogênica de Köberle 8 para explicar todas as "patias chagásicas". Para Köberle o destino do chagásico seria selado na fase aguda, quando a desnervação parassimpática ocorre. Entretanto, estudos realizados nas últimas décadas, vieram mostrar que sem miocardite importante não se instala a insuficiência cardíaca congestiva no chagásico crônico, ao passo que a desnervação, por vezes intensa, parece compativel com boa função contrátil do miocárdiol 49 .

Admitindo-se que as alterações inflamatórias do miocárdio têm participação na fisiopatogenia da cardiopatia chagásica crônica, para orientação de sua terapêutica, torna-se importante esclarecer os fatores responsáveis pelo seu aparecimento, manutenção e modulação. Uma série de estudos têm demonstrado, em chagásicos crônicos, a existência de auto-anticorpos (anti-EVI, antimiocárdio, antinervo, antineurônios) 6711121417 e de linfócitos capazes de agredir in vitro células miocárdicas 1516 . Esta resposta auto-imune, seria determinada pela antigenicidade cruzada entre $T$. cruzi e os tecidos do hospedeiro ${ }^{16}$, não se podendo também afastar o papel de antigenos liberados por células (miocardicas por exemplo) lesadas ou destruídas pelo parasita ou por outros mecanismos ${ }^{1}$. Por outro lado, alguns estudos sugerem que as formas amastigotas de $T$. cruzi podem liberar antígenos que são adsorvidos às miocélulas, modificando-lhes a antigenicidade e tornando-as alvo de agressão imunitária ${ }^{13}$. Em ambos os casos (antigenicidade cruzada ou adsorção antigênica), podem

\section{CARDIOPATHY AND PARASITISM IN PATIENTS WITH CHRONIC CHAGAS' DISEASE}

Acute chagasic myocarditis is accompanied by a rich parasitism ${ }^{18}$ which leaves little doubt as to the participation of Trypanosoma cruzi in the inflammatory reaction. In contrast, in the chronic phase, notably in chagasics who died from cardiac insufficiency, there is a discrepancy between the severity of the lesion and myocardial parasitism. Indeed it can be said that in the majority of the descriptions of the microscopy of both the heart and digestive tract tissue parasitism is not seen in the chronic phase of the disease. These facts, sufficient to raise doubts as to the necessity of persistence of trypanosome infection in the evolution of cardiopathy, were reinforced by the wide acceptance of the neurogenic theory of Köberle 8 to explain all chagasic pathologies. For Köberle the fate of the chagasic was sealed in the acute phase, when the parasympathetic denervation occurred. However, studies carried out in the last few decades have shown that without significant myocarditis congestive cardiac failure will not occur in the chronic chagasic patient. On the other hand, sometimes intense denervation is compatible with good contractile function of the myocardium 149 .

If one accepts that the myocardial inflammation participates in chronic chagasic cardiomyopathy, it becomes important when considering treatment to clarify the factors responsible for the appearance, persistence and modulation of this reaction. A series of studies have shown in chronic chagasics the existence of auto-antibodies (anti-Evi, anti-myocardial, antinerve, anti-neuron) 6711121417 and of lymphocytes capable of attacking in vitro myocardial cells 1516 . This autoimmune response is said to be determined by the cross antigenicity between $T$. cruzi and the host tissue. Also a role for antigens liberated by the cells (eg: myocardial) damaged by the parasite cannot be excluded and there may be other mechanisms 1 . Some studies suggest that the amastigotes of $T$. cruzi can liberate antigens which are adsorbed to the myocardial cells, modifying their antigenicity and transforming them into foci of immune aggression ${ }^{13}$. In both cases (cross antigenicity or antigenic adsorption) variations in the immune response induced by the parasite or the host may occur. Although autoimmunity is described 
estar envolvidas variaçoes da resposta imune induzidas pelo parasita ou por fatores dependentes do hospedeiro. Embora a auto-imunidade seja um fato. sua ação determinando uma auto-agressão miocardica nào e consequència necessária e nem se o fosse. não estariamos autorizados a admiti-la como único ou mais importante fator responsavel pela miocardite.

Quando se examinam os corações de chagási$\cos$ crónicos verifica-se que antes da instalação da insuficiència cardiaca congestiva. as alteraçōes inflamatórias são predominantemente exsudativas e focais, as vezes formando granulomas 9 . $\mathrm{Na}$ vigència de falência cardiaca esta reação inflamatoria focal persiste, embora. as vezes. se acompanhe de exsudato mononuclear difuso, alem de fibrose ${ }^{14}$. Embora o exsudato mononuclear difuso possa estar na dependència de mecanismos auto-imunes. nảo parece lógico admitir o mesmo para a lesão focal. granulomatosa ou não, que e uma caracteristica proeminente da miocardite chagásica ${ }^{34}$. seja de individuos assintomáticos, falecidos subitamente. ou em insuficiencia cardiaca. Estudos minuciosos de cortes seriados de miocardio vieram demonstrar que, em muitos desses focos, è possivel a identificação morfológica do parasita $^{2}$, o que o coloca como o mais provável responsável pelo desencadeamento da miocardite focal. Tais parasitas muitas vezes não são identificados em estudos microscópicos rotineiros por se terem desintegrado, sendo interessante a pesquisa de antigenos parasitarios com anticorpos marcados. Que os parasitas persistem no hospedeiro o demonstram estudos com xenodiagnostico, pesquisa de anticorpos liticos ${ }^{10}$ e estudos de cortes histológicos de vários tecidos ${ }^{5}$. A falta de um parasitismo maciço no periodo pos-agudo, mas provavelmente atuante na gênese de lesões miocárdicas, parece estar de acordo com o longo tempo de evolução ( 10 a 30 anos) necessário para determinar o aparecimento de insuficiència cardiaca. É interessante assinalar que muitas vezes a reação inflamatória se estabelece em torno de ninhos sem rotura previa e que parasitas se desintegram no interior de miocelulas 3 possivelmente con pouca chance de ganhar o interstício ou a circulaçào e infectar outras células. Nos últimos anos surgiram estudos mostrando que no tecido muscular liso os parasitas formam ninhos, sendo a reaçào inflamatória menos intensa que no miocárdio5. Uma destas sedes é a veia central das supra-renais, cujo intersticio parece ser rico em corticorteróides ${ }^{2}$. Pode-se admitir que, neste ambiente rico em hormônio, as defesas sejam menos eficientes e que o parasita consiga fazer ciclos de reinfecção endógena com mais facilidade que em outras partes do or- to what extent it determines the development of myocarditis is unclear.

When one examines the hearts of chronic chagasic patients it can be shown that, before the development of congestive heart failure, the inflammatory alterations are predominantly of a focal exudative nature sometimes forming granulomas 9 . With the onset of cardiac failure the focal inflammatory reaction persist but is sometimes accompanied by fibrosis and diffuse mononuclear exudate that may be dependent on autoimmune mechanisms ${ }^{14}$. The focal lesion, whether granulomatous or not, is not necessarily a prominent characteristic of chagasic myocarditis ${ }^{34}$ in asymptomatic individuals dying suddenly or in patients in heart failure meticulous studies of serial sections of myocardium show that in many of these foci it is possible to identify the parasite 2 . This is most likely to be responsible for this focal myocarditis. Many times amastigotes are not identified in routine microscopy studies because they have desintegrated. It would be interesting to look for parasitic antigens with specific antibodies. That parasites persist in the host is demonstrated by xenodiagnostic studies, the presence of lytic antibodies ${ }^{10}$, and studies of histological sections of various tissues 5 . Although many parasites are not present after the acute phase they are probably responsible for the genesis of myocardial lesions. Their small number may explain the long evolution period (10-30 years) before cardiac insufficiency appears. It is interesting to note that many time the inflammatory reaction is established around unruptured amastigote nests. Parasites which desintegrate in the interior of myocells 3 have little chance to gain the interstitium or circulation to infect other cells. In the last few years studies suggest that in smooth muscle the parasites form nests with a less intense reaction than in the myocardium ${ }^{5}$. One of the sites where this has been studied is the central vein of the suprarenal where the wall of this vessel could be rich in corticosteroids ${ }^{2}$. Since there may be a localised hormonal effect it may be that host defenses are less efficient. As a result the parasite may multiply with more facility than in other parts of the organism. We recently had the opportunity to autopsy a young chagasic patient who had cardiac failure that was difficult to control and died 18 months after the onset of symptoms. The myocardium showed an accentuated exudative inflammation with little fibrosis. Amastigote nests were found in each ten slides examined (5 $u$ m sections). In the musculature of the suprarenal vein one to two dozen amastigote nests, some with elonganismo. É de interesse relatar observação recente de 
chagásico crônico, jovem, que veio a falecer em insuficiência cardíaca de difícil controle, ano e meio após seu início. $\mathrm{O}$ miocárdio apresentava inflamação crônica com acentuada atividade exsudativa, fibrose pouco intensa, sendo encontrado um ninho de amastigota em cada 10 lâminas $(5 \mu \mathrm{m})$ examinadas. $\mathrm{Na}$ musculatura lisa da veia central da supra-renal observamos uma a duas dezenas de ninhos contendo formas amastigotas e formas alongadas (epi e tripomastigotas, provavelmente), por lâmina examinada. Esta observação e os outros fatos aqui apresentados não afastam a participação de auto-imunidade na fase crônica da doença de Chagas, mas dão suporte à tese de que a permanência do $T$. cruzi no organismo participa da gênese das lesões miocárdicas e, portanto, na evolução da cardiopatia.

\section{REFERÊNCIAS BIBLIOGRÁFICAS}

1. Almeida HO. A cardiopatia em chagásicos crônicos com e sem "megas". Tese Professor Titular, Faculdade de Medicina do Triângulo Mineiro, 1982.

2. Almeida HO, Teixeira VPA, Oliveira ACF. Flebite com parasitismo em supra-renais de chagásicos crònicos. Arquivos Brasileiros de Cardiologia 36: 341-344, 1981.

3. Almeida HO, Teixeira VPA, Gobbi H, Rocha A, Brandão MC. Inflamação associada a células musculares cardiacas parasitadas pelo Trypanosoma cruzi em chagásicos crônicos. Arquivos Brasileiros de Cardiologia 42: 183-186, 1984.

4. Almeida HO, Gobbi H, Teixeira VPA, Araújo WF, Fernandes PA. Aspectos da miocardite em chagásicos crônicos com "megas" e sem "megas" com insuficiência cardiaca congestiva. Revista da Sociedade Brasileira de Medicina Tropical 17: 81-88, 1984.

5. Barbosa Jr AA, Andrade ZA. Identificação do Trypanosoma cruzi nos tecidos extracardíacos de portadores de miocardite crônica chagásica. Revista da Sociedade Brasileira de Medicina Tropical 17: 123-126, 1984.

6. Cóssio PM, Diez C, Szarfman A, Kreutzer E, Candiolo B, Arana RH. Chagasic cardiopathy. I. Demonstration of a serum gamma globulin factor which reacts with endocardium and vascular structures. Circulation 49: 13-21, 1974.

7. Cóssio PM, Laguens RP, Diez C, Szarfman A, Segal A, Arana RH. Chagasic cardiopathy: Antibodies reacting with plasma membrane of striated muscle and endothelial cells. Circulation 50: 1252-1259, 1974. gated forms (epimastigotes and trypomastigotes) were found in each slide. These observations and others discussed here do not exclude the participation of autoimmunity in the chronic phase of Chagas' disease but give support to the thesis that the persistence of $T$. cruzi in the host participates in the genesis of the cardiopathy.

8. Köberle F. Cardiopatia chagásica. O Hospital 53: 311 $346,1958$.

9. Lopes ER, Chapadeiro E, Andrade ZA, Almeida HO, Rocha A. Anatomia patológica de coraçōes de chagásicos assintomáticos falecidos de modo violento. Memórias do Instituto Oswaldo Cruz 76: 189-197, 1981.

10. Lopes ER, Pereira MES, Moraes CA, Krettli AU, Brener Z. Anticorpos liticos detectados em liquido pericárdico de chagásicos crônicos. Revista da Sociedade Brasileira de Medicina Tropical 17: 127-131, 1981.

11. Peralta JM, Manigot DA, Muscelli EOA, Magalhães TCR, Almeida EA, Bastos A. Anticorpos EVI e NP na infecção chagásica crô ¿a. Estudo em pacientes com diferentes formas clinicas. Revista do Instituto de Medicina Tropical ue São Paulo 24: 6, 1982.

12. Ribeiro dos Santos E, Hudson L. Trypanosoma cruzi: adsorption of parasite antigens to mammalian cell surfaces. Parasite Immunology 2: 1-10, 1980.

13. Ribeiro dos Santos R, Marquez JO, Von Gal Furtado CC, Ramos de Oliveira JC, Martins AR, Köberle F. Antibodies against neurons in chronic Chagas' disease. Tropenmedizine und Parasitologie 30: 19-25, 1979.

14. Teixeira ARL. Competència imunológica do paciente chagásico. Tese de Doutorado, Universidade Federal de Minas Gerais. 1979.

15. Teixeira ARL, Teixeira G, Macedo V, Prata A. Trypanosoma cruzi - sensitized $\mathrm{T}$ lymphocyte mediated ${ }^{51} \mathrm{Cr}$ release from human heart cells in Chagas" disease. American Journal of Tropical Medicine and Hygiene 27: 1097-1107, 1978.

16. Tressa E. Anticorpos antimiocárdio demonstrados por imunofluorescência indireta no soro de portadores de doença de Chagas crônica. Correlação entre os resultados sorológicos e as alterações eletrocardiográficas. Tese, Universidade Estadual Paulista, Botucatu, 1972.

17. Torres CBM, Duarte E. Miocardite na forma aguda da doença de Chagas. Memórias do Instituto Oswaldo Cruz 46: 759-793, 1948.
Hipólito de Oliveira Almeida
Disciplina de Patologia Geral
Faculdade de Medicina do Triângulo Mineiro Uberaba, Minas Gerais 